\title{
Removal of Imidacloprid Pesticide by Electrocoagulation Process using Iron and aluminum Electrodes
}

\section{Nasser Ghalwa MA* and Nader Farhat B}

Chemistry Department, Al-Azhar University, Gaza, Palestine

\begin{abstract}
The main purpose of this work the removal efficiency of the pesticide imidacloprid and chemical oxygen demand (COD) from aqueous solution using the electrocoagulation process. The effect of several parameters such as initial $\mathrm{pH}$, initial imidacloprid concentration, current density, type of electrolyte, salt concentration, and temperature on the pesticide and COD removal efficiency was investigated on EC performance. The obtained results showed that imidacloprid and COD removal were $95 \%$ and $89.5 \%$ by using Fe electrodes at 60 min and were $80.8 \%$ and $73.1 \%$ by using $\mathrm{Al}$ electrodes at $90 \mathrm{~min}$. Pesticide removal kinetic followed pseudo second and first order kinetics using Fe and Al electrodes respectively. It can be concluded that electrocoagulation process by Fe electrode is very efficient and clean process for imidacloprid removal and COD from wastewater.
\end{abstract}

Keywords: Electrocoagulation; Aluminum; Iron; Electrode; Imidacloprid; Pesticide; Water treatment

\section{Introduction}

The wide use of pesticides gives rise to serious ecological problems due to their negative environmental effects. The water contamination by pesticides is an important problem that the scientists are dealing with over the year [1,2]. Imidacloprid [1-(6-chloro-3-pyridylmethyl)-N-nitroimidazolidin-2-ylideneamine] is a widely used insecticide introduced for agricultural use in the 1990s, and it is mainly used at the present to control sucking insects in crops (e.g., aphids, thrips, whiteflies and termites) [3,4]. Imidacloprid belongs to the nicotinoid chemical family. Because of their molecular shape, size, and charge, nicotinoid fit into receptor molecules in the nervous system that normally receive the molecule acetylcholine; Imidacloprid is toxic to some species of aquatic animals at extremely low concentrations [3], And classified by the EPA as a class II/III agent [5]. Imidacloprid is moderately toxic if ingested. Oral LD50 values in rats were estimated to be $450 \mathrm{mg} / \mathrm{kg}$ for both sexes in one study and 500 and $380 \mathrm{mg} / \mathrm{kg}$ in males and females, respectively in another study. In mice, LD50 values were estimated at $130 \mathrm{mg} / \mathrm{kg}$ for males and $170 \mathrm{mg} /$ $\mathrm{kg}$ for females. Imidacloprid is very low in toxicity via dermal exposure. The dermal LD50 in rats was estimated at greater than $5000 \mathrm{mg} / \mathrm{kg}$ [6]. There are several methods to remove the imidacloprid from water, such as treatment by photolysis [7], photo-Fenton [8], ozonation [9], electrocatalytic oxidation [10] and electrofenton oxidation [11]. Most practical methods are the application of electrocoagulation (EC) which is an electrochemical wastewater treatment technology. The EC process has many advantages like simple equipment requirement, easy operation, no chemical use requirement, rapid sedimentation, sludge stability, low sludge production, and environmental compatibility. It has successfully been employed for the treatment of different wastewaters such as from hospitals [12], baker's yeast [13], laundries [14], biodiesel [15,16], and slaughter houses [17], wastewaters including surfactants [18], fluoride [19] and heavy metal-containing solutions [20,21]. Different technological processes such as adsorption [22], biodegradation [23,24], nanofiltration [25], electrocoagulation, electrochemical reduction and oxidation, indirect electro-oxidation with strong oxidants, and photocatalytic degradation [26,27], for the removal of pesticides have been reported recently. EC is an electrochemical has attracted increasing interest as a promising powerful method for efficiently removing pesticides from water such as Malathion [28], methyl parathion, atrazine and triazophos [29], Malathion, imidacloprid and chlorpyrifos [30], and abamectin [31]. This study involves the investigated removal efficiency and COD of imidacloprid using iron and aluminum electrodes in aqueous solution by electrocoagulation method.

\section{Experiment}

\section{Chemicals}

The pesticide used in the present work was imidacloprid, Pesticide Solutions, imidacloprid solutions were prepared from the commercially available pesticide, in distilled water, imidacloprid also known as (konfidor) $350 \mathrm{SC}$, at a concentration of $350 \mathrm{~g}$ $\mathrm{L}^{-1}$. This concentration is the same as that used by farmers during strawberry cultivation. The properties of the imidacloprid are given in Table 1.

Sodium chloride, potassium chloride, Sodium sulfate, Sodium carbonate, sodium hydroxide, sulfuric acid, potassium dichromate, was of analytical grade and purchased from Merck. Distilled water was used for the preparation of solutions. Standard solutions of potassium dichromate $\left(\mathrm{K}_{2} \mathrm{Cr}_{2} \mathrm{O}_{7}\right)$, sulfuric acid $\left(\mathrm{H}_{2} \mathrm{SO}_{4}\right)$ reagent with silver sulfate $\left(\mathrm{Ag}_{2} \mathrm{SO}_{4}\right)$, Mercury sulfate $\left(\mathrm{HgSO}_{4}\right)$ and were prepared to measure the COD. A stock solution of pesticide $(500 \mathrm{mg} / \mathrm{L})$ was prepared by dissolving an accurate quantity of the pesticide in distilled water and suitably diluted to the required initial concentrations. Different standard solutions of pesticide with concentration from $30-150 \mathrm{mg} \mathrm{L}^{-1}$ were prepared to measure its removal at different conditions. The $\mathrm{pH}$ of the working solution was adjusted to the desired values with $0.1 \mathrm{~N}$ $\mathrm{HCl}$ or $0.1 \mathrm{~N} \mathrm{NaOH}$.

\section{Equipments and procedures}

The electrocoagulation unit consisted of a $100 \mathrm{ml}$ electrochemical reactor with iron and aluminum electrodes with an effective surface area of $5.4 \mathrm{~cm}^{2}$. The electrodes were $17 \mathrm{~mm} \times 10 \mathrm{~mm}$ and inter electrodes distance was $1 \mathrm{~cm}$. The electrodes were positioned vertically and parallel to each other. The current density was maintained constant by means of a precision DC power supply; model (DZ040019) EZ Digital CO. Ltd. (Korea). The pesticide concentration was determined using a double -

*Corresponding author: Nasser Abu Ghalwa, Chemistry Department, Al-Azhar University, Gaza, Palestine, Tel: 091-846547; E-mail: dr.nasser.galwa@hotmail.com

Received August 01, 2015; Accepted August 13, 2015; Published August 20, 2015

Citation: Nasser Ghalwa MA, Nader Farhat B (2015) Removal of Imidacloprid Pesticide by Electrocoagulation Process using Iron and aluminum Electrodes. J Environ Anal Chem 2: 154. doi:10.4172/2380-2391.1000154

Copyright: (ㄷ 2015 Nasser Ghalwa MA, et al. This is an open-access article distributed under the terms of the Creative Commons Attribution License, which permits unrestricted use, distribution, and reproduction in any medium, provided the original author and source are credited. 
Citation: Nasser Ghalwa MA, Nader Farhat B (2015) Removal of Imidacloprid Pesticide by Electrocoagulation Process using Iron and aluminum Electrodes. J Environ Anal Chem 2: 154. doi:10.4172/2380-2391.1000154

\begin{tabular}{|l|l|}
\hline pesticide & Imidacloprid \\
\hline Chemical structure & $\mathrm{C}$ \\
\hline Chemical formula & $\left.\mathrm{M}(255.7) \mathrm{g} \cdot \mathrm{mol}^{-1}\right)$ \\
\hline Molecular weight $(\mathrm{g} / \mathrm{mol})$ & $270 \mathrm{~nm}$ \\
\hline$\lambda_{\max }$ & \\
\hline
\end{tabular}

Table 1: Properties of Imidacloprid.

beam Uv-Vis spectrophotometer, model UV 1601 is from Shimadzu (Japan) at $270 \mathrm{~nm}$. Hot Plate, model (HB502), BIBBY STERILIN LTD. (U.K.). A pH meter model AC28, TOA electronics Ltd., (Japan). Water bath model SB-650, Tokyo Kikakkai CO. Ltd., (Japan). A closed reflux colorimetric unit was used for the COD determination. Chemical Oxygen Demand (COD), HANNA instruments, Thermo reactor, model C9800 Reactor in Hungary - Europe.

\section{Analysis}

Two main parameters were measured to evaluate the electrochemical treatment efficiency, the remaining pollutant concentration and the COD. Remaining pollutants (imidacloprid) concentration was measured with the double-beam UV-visible spectrophotometer at $\lambda=270 \mathrm{~nm}$ using calibration curve with standard error $\pm 0.5 \%$. The COD was determined using a closed reflux colorimetric method. The equation used to calculate the pesticide removal efficiency in the treatment experiments was:

$$
\% \mathbf{E}=\left[\left(\mathbf{A}_{\mathbf{0}}-\mathbf{A}\right) / \mathbf{A}_{\mathbf{0}}\right] \times \mathbf{1 0 0}
$$

Where $\mathbf{A}_{o}$ and $\mathbf{A}$ are absorbance values of pesticide solutions before and after treatment with respect to their $\lambda_{\max }[32]$.

The calculation of COD removal efficiencies after electrocoagulation treatment was performed using the following formula [33].

$$
\mathbf{C}_{\mathbf{R}}(\%)=\left[\left(\mathbf{C}_{\mathbf{0}}-\mathbf{C}\right) / \mathbf{C}_{\mathbf{0}}\right] \times \mathbf{1 0 0}
$$

Where $\mathrm{C}_{\circ}$ and $\mathrm{C}$ are concentrations of wastewater before and after electrocoagulation.

\section{Result and discussion}

\section{Mechanism of electrocoagulation process}

The mechanism of the electrochemical process in aqueous systems is well known. There are three possible mechanisms involved in the process, i.e. electrocoagulation, electroflotation and electro-oxidation. In EC, with electrical current flowing between two electrodes, the coagulant is generated in situ by electrolytic oxidation of the anode material. By using an iron and aluminum anode the $\mathrm{Fe}(\mathrm{OH})_{\mathrm{n}}$ and $\mathrm{Al}(\mathrm{OH})_{\mathrm{n}}$ formation with $\mathrm{n}=2$ or 3 is released at the anode [32-34].

\section{EC using iron electrodes}

\section{Mechanism 1:}

At anode:

$$
\begin{aligned}
& 4 \mathrm{Fe}(s) \rightarrow 4 \mathrm{Fe}^{2+}{ }_{(a q)}+8 e^{-} \\
& 4 \mathrm{Fe}_{(a q)}^{2+}+10 \mathrm{H}_{2} \mathrm{O}_{(l)}+\mathrm{O}_{2(g)} \rightarrow 4 \mathrm{Fe}(\mathrm{OH})_{3(s)}+8 \mathrm{H}_{(a q)}^{+}
\end{aligned}
$$

At cathode:

$$
8 H_{(a q)}^{+}+8 e^{-} \rightarrow 4 H_{2(g)}
$$

Overall:

$$
4 \mathrm{Fe}_{(s)}+10 \mathrm{H}_{2} \mathrm{O}_{(l)}+\mathrm{O}_{2(g)} \rightarrow 4 \mathrm{Fe}(\mathrm{OH})_{3(s)}+4 \mathrm{H}_{2(g)}
$$

Mechanism 2:

At anode:

$$
\begin{aligned}
& \mathrm{Fe}_{(s)} \rightarrow \mathrm{Fe}_{(a q)}^{2+}+2 e^{-} \\
& \mathrm{Fe}_{(a q)}^{2+}+2 \mathrm{OH}_{(a q)}^{-} \rightarrow \mathrm{Fe}(\mathrm{OH})_{2(s)}
\end{aligned}
$$

At cathode:

$$
2 \mathrm{H}_{2} \mathrm{O}_{(l)}+2 e \rightarrow \mathrm{H}_{2(g)}+2 \mathrm{OH}_{(a q}^{-}
$$

Overall:

$$
\mathrm{Fe}_{(s)}+2 \mathrm{H}_{2} \mathrm{O}_{(l)} \rightarrow \mathrm{Fe}(\mathrm{OH})_{2(s)}+\mathrm{H}_{2(g)}
$$

EC using aluminum electrodes follows:

The electrochemical reaction with $\mathrm{Al}$ anode can be summarized as

At anode:

$$
\begin{aligned}
& A l(s) \rightarrow 2 A l^{3+}(a q)+6 e^{-} \\
& 2 A l^{3+}(a q)+6 H 2 O(l) \rightarrow 2 A l(O H) 3(s)+6 H^{+}(a q)
\end{aligned}
$$

At cathode:

$$
6 H^{+}(a q)+6 e^{-} \rightarrow 3 H 2(g)
$$

Overall:

$$
2 \mathrm{Al}(s)+6 H 2 O(l) \rightarrow 2 \mathrm{Al}(\mathrm{OH}) 3(s)+3 H 2(\mathrm{~g})
$$

The generation of metal hydroxides $[\mathrm{Fe}(\mathrm{OH}) \mathrm{n}$ and $\mathrm{Al}(\mathrm{OH}) \mathrm{n}]$ are followed by an increase in the concentration of colloids (usually negatively charged) in the region close to the anode [35]. The produced ferrous ions hydrolyze to form monomeric hydroxide ions and polymeric hydroxide complexes that depend on the $\mathrm{pH}$ of the solution. The polymeric hydroxides, which are highly charged cations, destabilize the negatively charged colloidal particles allowing the formation of flocks. When the amount of iron in the solution exceeds the solubility of the metal hydroxide, the amorphous metal hydroxide precipitates is formed, which causes sweep flock coagulation [36].

\section{Effect of electrolyte concentration}

To evaluate the effect of the salt concentration on imidacloprid removal efficiency and COD, different electrolyte solutions were prepared by the addition of different amounts of $\mathrm{NaCl}$ varied from $(0.5$ $-3 \mathrm{~g} / \mathrm{L}$ ) at a current density of $18.5 \mathrm{~mA} / \mathrm{cm}^{2}$, initial concentration 50 $\mathrm{mg} \mathrm{L}^{-1}$, inter electrode distance of $1 \mathrm{~cm}, \mathrm{pH}$ of 6.9 and temperature of $20^{\circ} \mathrm{C}$. NaCl was used as a supporting electrolyte to increase the solution conductivity. Figure 1 and Table 2 shows that the pesticide removal efficiency increased from 76.5 to $95 \%$ using $(\mathrm{Fe})$ and 67 to $80 \%$ using (Al) electrodes, and COD from 65 to $89.5 \%$ using $(\mathrm{Fe})$ and 51 to $73 \%$ electrodes. As the $\mathrm{NaCl}$ concentration increased from 0.5 to $1 \mathrm{~g} / \mathrm{L}$. We can see from Figure 1 that increases in the amount of $\mathrm{NaCl}$ results in increasing removal efficiency. Therefore, we thought that the EC in the presence of $\mathrm{NaCl}$ could improve the imidacloprid removal efficiency by increasing the availability of metal coagulants in the solution and by leading to a reduction of the oxide layer and an enhancement of the anodic dissolution of the electrode material [37].

\section{Effect of current density}

Current density is very important parameter that affects the 
Citation: Nasser Ghalwa MA, Nader Farhat B (2015) Removal of Imidacloprid Pesticide by Electrocoagulation Process using Iron and aluminum Electrodes. J Environ Anal Chem 2: 154. doi:10.4172/2380-2391.1000154

Page 3 of 7

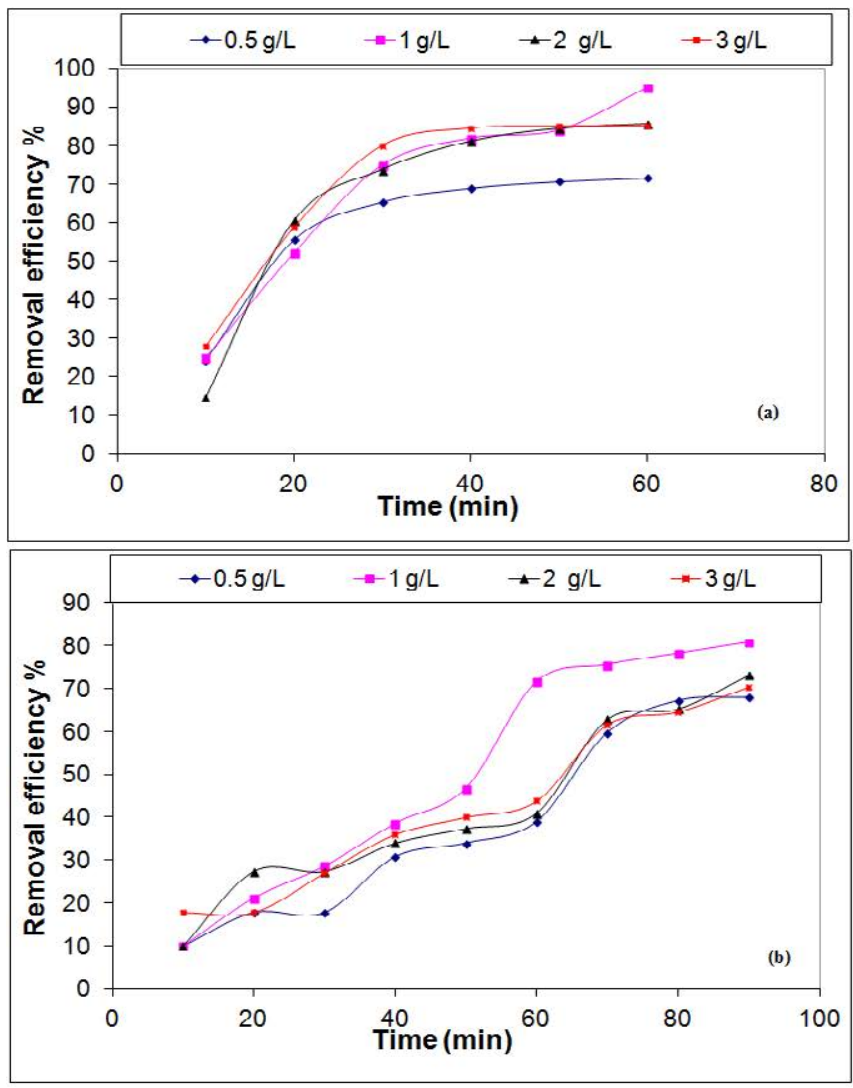

Figure 1: Effect of electrolyte concentration on the efficiency of imidacloprid removal using $\mathrm{Fe} \mathrm{(a)} \mathrm{and} \mathrm{Al}$ (b) electrodes. Initial concentration of the pesticide $=50 \mathrm{mg} / \mathrm{L}$, volume of the solution $=100 \mathrm{ml}$, current density of $18.5 \mathrm{~mA} / \mathrm{cm}^{2}$, $\mathrm{pH}=6.9$, inter electrode distance $=1 \mathrm{~cm}$, dimension of the electrodes $=17 \mathrm{~mm}$ $\times 10 \mathrm{~mm}$ and temperature $=20^{\circ} \mathrm{C}$

electrocoagulation process because it directly determines both coagulant dosage and bubble generation rates and strongly influences both solution mixing and mass transfer at the electrodes. So current density is the key operational parameter that affecting the system's response time and also influencing the dominant pollutant separation mode [38].

To examine the effect of current density on removal efficiency of imidacloprid and COD, a series of experiments were carried out with the current density being varied from $9-55 \mathrm{~mA} / \mathrm{cm}^{2}$. At initial concentration of $50 \mathrm{mg} \mathrm{L}^{-1}$, inter electrode distance of $1 \mathrm{~cm}$, pH of 6.9 , $\mathrm{NaCl}$ concentration of $1 \mathrm{~g} \mathrm{~L}^{-1}$ and temperature of $20^{\circ} \mathrm{C}$. Figure 2 and Table 2 show the effect of current density for the removal of pesticide and COD from aqueous solutions. The removal efficiency of imidacloprid and COD increased up to $95 \%$ and $89.5 \%$ using Fe electrodes at 60 min and $80 \%$ and $73 \%$ using $\mathrm{Al}$ electrodes at $90 \mathrm{~min}$. At high current densities, the generation of $\mathrm{Fe}$ and $\mathrm{Al}$ ions increases due to the increase of anodic dissolution, resulting in a greater pesticide removal rates, indicating that the adsorption depends up on the availability of binding sites for imidacloprid.

\section{Effect of temperature}

The electrochemical reaction rate like any other chemical reactions rate increases when temperature of solution increases. In the present work, effect of temperature from 10 to $40^{\circ} \mathrm{C}$ has been studied for the imidacloprid removal efficiency and COD at a current density of 18.5 $\mathrm{mA} / \mathrm{cm}^{2}$, initial concentration of $50 \mathrm{mg} \mathrm{L}^{-1}$, inter electrode distance of
$1 \mathrm{~cm}, \mathrm{pH}$ of 6.9 and $\mathrm{NaCl}$ concentration of $1 \mathrm{~g} \mathrm{~L}^{-1}$. Figure 3 and Table 2 indicate that increasing temperature has a negative effect on removal efficiency of pesticide and COD, where at $20^{\circ} \mathrm{C}$ the pesticide removal and $\mathrm{COD} \%$ reached to maximum. While at higher temperature value ( 30 and $40^{\circ} \mathrm{C}$ ) the pesticide removal and COD\% dropped to low values. In this case, the volume of colloid $\mathrm{M}(\mathrm{OH})$ will decrease and pore production on the metal anode well be closed [38].

\section{Effect of initial $\mathrm{pH}$}

It has been established that the influent $\mathrm{pH}$ is an important operating factor influencing the performance of electrochemical process [39]. These experiments were carried out to evaluate the effect of $\mathrm{pH}$, using solutions containing a sample with an initial $\mathrm{pH}$ varying in the range (2.4-10) at initial concentration of $50 \mathrm{mg} \mathrm{L}^{-1}$, inter electrode distance of $1 \mathrm{~cm}$, a current density of $18.5 \mathrm{~mA} / \mathrm{cm}^{2}, \mathrm{NaCl}$ concentration of $1 \mathrm{~g} \mathrm{~L}^{-1}$ and temperature of $20^{\circ} \mathrm{C}$. Figure 4 and Table 3 shows the pesticide removal efficiency and $\mathrm{COD}$ after 60 min using $(\mathrm{Fe})$ and 90 min using $(\mathrm{Al})$ electrodes as a function of $\mathrm{pH}$. In $(\mathrm{Fe})$ electrode Figure 4 (a) the removal efficiency of the pesticide and COD is higher in neutral medium (PH6.9), meanwhile, in acidic and alkaline are less. In $\mathrm{Al}$ electrodes Figure 4(b) the removal efficiency of the pesticide and COD is low in acidic medium (PH 2.4 and 5.2), meanwhile higher efficiencies were recorded in 6.9-10 $\mathrm{pH}$ range which is close to the optimal $\mathrm{pH}$ for $\mathrm{AI}(\mathrm{OH})_{3}$ solid formation. The flocks of $\mathrm{Al}(\mathrm{OH})_{3(\mathrm{~s})}$ have large surface areas, which are useful for a rapid adsorption of soluble organic compounds and trapping of colloidal particles [40].

\section{Effect of initial concentration of pesticide}

The effect of initial pesticide concentration on the pesticide removal

\begin{tabular}{|c|c|c|c|c|c|}
\hline \multicolumn{6}{|c|}{$\mathrm{Fe}(\mathrm{a})$} \\
\hline- & 55 & 37 & 18.5 & 9 & Current density $\left(\mathrm{mA} / \mathrm{cm}^{2}\right)$ \\
\hline- & 50.2 & 50.7 & 89.5 & 65.5 & $\operatorname{COD}(\%)$ \\
\hline 10 & 8 & 6.9 & 5.2 & 2.5 & $\mathrm{pH}$ \\
\hline \multirow[t]{2}{*}{84} & 84.2 & 89.5 & 83 & 85 & $\operatorname{COD}(\%)$ \\
\hline & $\mathrm{Na}_{2} \mathrm{SO}_{4}$ & $\mathrm{NaCl}$ & $\mathrm{Na} 2 \mathrm{CO} 3$ & $\mathrm{KCl}$ & Electrolyte \\
\hline- & 47.7 & 89.5 & 26.8 & 31.3 & $\operatorname{COD}(\%)$ \\
\hline- & 3 & 2 & 1 & 0.5 & {$[\mathrm{NaCl}](\mathrm{g} / \mathrm{L})$} \\
\hline- & 72.2 & 76 & 89.5 & 65 & COD (\%) \\
\hline - & 150 & 100 & 50 & 30 & [PESTICIDE] (mg/L) \\
\hline- & 38.8 & 59.7 & 89.5 & 86.5 & $\operatorname{COD}(\%)$ \\
\hline- & 40 & 30 & 20 & 10 & $\begin{array}{l}\text { Temperature } \\
\left({ }^{\circ} \mathrm{C}\right)\end{array}$ \\
\hline- & 82 & 83.5 & 89.5 & 71.6 & COD $(\%)$ \\
\hline \multicolumn{6}{|c|}{$\mathrm{Al}(\mathrm{b})$} \\
\hline & 55 & 37 & 18.5 & 9 & Current density $\left(\mathrm{mA} / \mathrm{cm}^{2}\right)$ \\
\hline & 61.1 & 65.6 & 73.1 & 55.2 & $\operatorname{COD}(\%)$ \\
\hline 10 & 8 & 6.9 & 5.2 & 2.4 & $\mathrm{pH}$ \\
\hline \multirow[t]{2}{*}{65.6} & 67.1 & 73.1 & 61.1 & 32.8 & $\operatorname{COD}(\%)$ \\
\hline & $\mathrm{Na}_{2} \mathrm{SO}_{4}$ & $\mathrm{NaCl}$ & $\mathrm{Na} 2 \mathrm{CO} 3$ & $\mathrm{KCl}$ & Electrolyte \\
\hline- & 63.1 & 73.1 & 45 & 60.1 & $\operatorname{COD}(\%)$ \\
\hline- & 3 & 2 & 1 & 0.5 & {$[\mathrm{NaCl}](\mathrm{g} / \mathrm{L})$} \\
\hline- & 52.1 & 54.3 & 73.1 & 50 & COD (\%) \\
\hline- & 150 & 100 & 50 & 30 & [PESTICIDE] (mg/L) \\
\hline- & 56 & 65.6 & 73.1 & 76.1 & $\operatorname{COD}(\%)$ \\
\hline- & 40 & 30 & 20 & 10 & Temperature $\left({ }^{\circ} \mathrm{C}\right)$ \\
\hline- & 70.1 & 71.6 & 73.1 & 64.1 & $\operatorname{COD}(\%)$ \\
\hline
\end{tabular}

Table 2: Effect of current density, $\mathrm{pH}$, type of electrolyte, concentration electrolyte, pesticide concentration, and temperature on the efficiency of COD removal for imidacloprid using $\mathrm{Fe}(\mathrm{a})$ and $\mathrm{Al}(\mathrm{b})$ electrodes. Initial concentration of the pesticide $=50 \mathrm{mg} / \mathrm{L}$, volume of the solution $=100 \mathrm{ml}$, $[\mathrm{NaCl}]$ concentration $=1 \mathrm{~g} / \mathrm{L}$, a current density of $18.5 \mathrm{~mA} / \mathrm{cm}^{2}, \mathrm{pH}=6.9$, inter electrode distance $=1 \mathrm{~cm}$, dimension of the electrodes $=17 \mathrm{~mm} \times 10 \mathrm{~mm}$ and temperature $=20^{\circ} \mathrm{C}$. 
Citation: Nasser Ghalwa MA, Nader Farhat B (2015) Removal of Imidacloprid Pesticide by Electrocoagulation Process using Iron and aluminum Electrodes. J Environ Anal Chem 2: 154. doi:10.4172/2380-2391.1000154

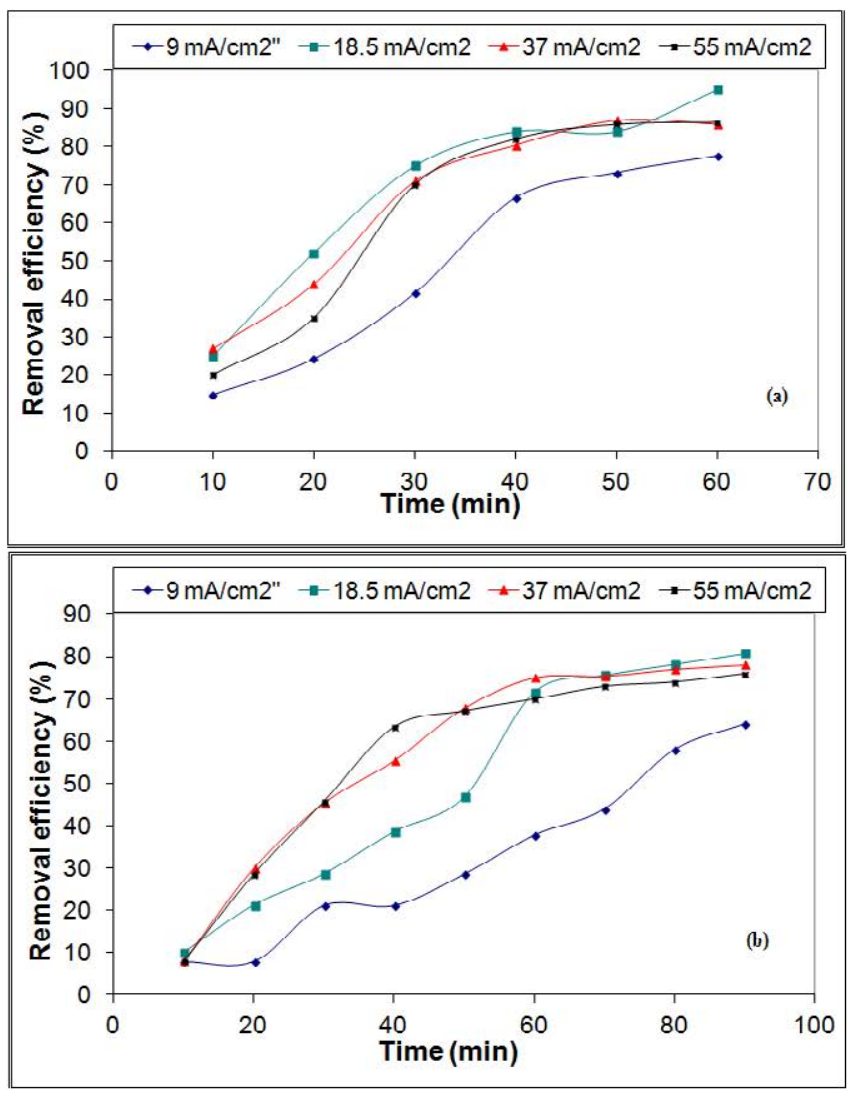

Figure 2: Effect of current density on the efficiency of imidacloprid removal using $\mathrm{Fe} \mathrm{(a)} \mathrm{and} \mathrm{Al}(\mathrm{b})$ electrodes. Initial concentration of the pesticide $=50$ $\mathrm{mg} / \mathrm{L}$, volume of the solution $=100 \mathrm{ml}, \mathrm{NaCl}$ concentration $=1 \mathrm{~g} / \mathrm{L}, \mathrm{pH}=6.9$, inter electrode distance $=1 \mathrm{~cm}$, dimension of the electrodes $=17 \mathrm{~mm} \times 10 \mathrm{~mm}$ and temperature $=20^{\circ} \mathrm{C}$.

was examined with solutions including pesticide of 30,50, 100 and 150 $\mathrm{mg} / \mathrm{L}$ at a current density of $18.5 \mathrm{~mA} / \mathrm{cm}^{2}, \mathrm{pH}$ of 6.9 , inter electrode distance of $1 \mathrm{~cm}, \mathrm{NaCl}$ concentration of $1 \mathrm{~g} \mathrm{~L}^{-1}$ and temperature $20^{\circ} \mathrm{C}$. According to the Figure 5 and Table 2, it may be seen that increasing initial pesticide concentration results in decreasing removal efficiency. In fact, when the initial concentration varied from 50 to $150 \mathrm{mg} / \mathrm{L}$, the removal percentage was $95 \%$ and $79 \%$ using $(\mathrm{Fe})$ and $80 \%$ and $66 \%$ using ( $\mathrm{Al})$. Adsorption on iron and aluminium hydroxide is the main pesticide molecule removal pathway. So, for a constant current intensity, there is obviously the same amount of electrogenerated iron and aluminium cations and hence the same amount of coagulating species. It is more likely that with increasing the initial pesticide concentration, less adsorption sites are available to capture organic pesticide molecules in excess $[41,42]$.

\section{Effect of type of electrolyte}

Figure 6 and Table 2 explain the effect of electrolyte type on the removal efficiency of imidacloprid and COD at $60 \mathrm{~min}$ using $\mathrm{Fe}$ and 90 min using $\mathrm{Al}$ electrodes in the presence of different supporting electrolytes including $\mathrm{NaCl}, \mathrm{KCl}, \mathrm{Na}_{2} \mathrm{SO}_{4}$ and $\mathrm{Na}_{2} \mathrm{CO}_{3}$, was studied at initial concentration of $50 \mathrm{mg} \mathrm{L}^{-1}$, a current density of $18.5 \mathrm{~mA} / \mathrm{cm}^{2}$, inter electrode distance of $1 \mathrm{~cm}$, a temperature of $20^{\circ} \mathrm{C}$ and $\mathrm{pH}$ of 6.9 . According to Figure 6 and Table 2, pesticide removal at $\mathrm{NaCl}$, is better than $\mathrm{KCl}, \mathrm{Na}_{2} \mathrm{CO}_{3}$ and $\mathrm{Na}_{2} \mathrm{SO}_{4}$. Higher elimination of pesticide and $\mathrm{COD}$ in the presence of $\mathrm{NaCl}(95 \%)$ and (89.5\%) using $\mathrm{Fe}$ electrodes and $(80 \%)$ and $(73 \%)$ using $\mathrm{Al}$ electrodes respectively, may be due to higher ionization of this compound. Due to formation of hypochlorite $(\mathrm{OCl})$ and hypochlorous acid $(\mathrm{HOCl})$. It is well known that $\mathrm{Cl}^{-}$anions can destroy the formed passivation layer on electrode and therefore enhance anodic dissolution rate of metal which lead to produce more metal hydroxide $[43,44]$.

\section{Kinetic studies}

Kinetics studies have important role in determining the rate constant and the order of reaction of this treatment removal [45]. So, rate constant is very significant in the design of wastewater treatment units. It is very essential to know the type of reaction rates for design a wastewater treatment unit. Rate of reaction describes the rates of change in concentration of reactant per unit time. Figures 7 (a) and
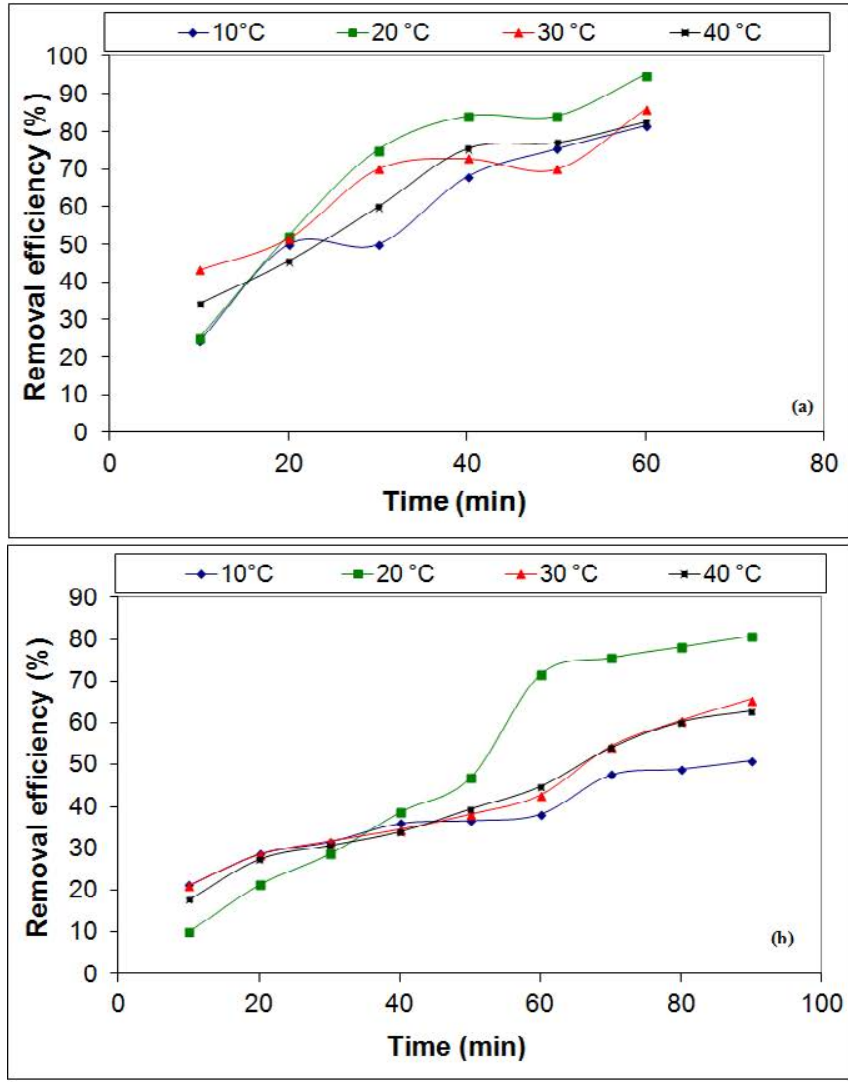

Figure 3: Effect of temperature on the efficiency of imidacloprid removal using $\mathrm{Fe} \mathrm{(a)} \mathrm{and} \mathrm{Al}$ (b) electrodes. Initial concentration of the pesticide $=50 \mathrm{mg} / \mathrm{L}$, volume of the solution $=100 \mathrm{ml}$, current density of $18.5 \mathrm{~mA} / \mathrm{cm}^{2}, \mathrm{pH}=6.9, \mathrm{NaCl}$ concentration $=1 \mathrm{~g} / \mathrm{L}$, dimension of the electrodes $=17 \mathrm{~mm} \times 10 \mathrm{~mm}$ and inter electrode distance $=1 \mathrm{~cm}$.

\begin{tabular}{|l|l|l|l|l|}
\hline Pesticide & Type of degradation & Reference & Removal \% & Time \\
\hline Imidacloprid & Photolys is & P. N. Moza et al. [7] & $90 \%$ & 4 hours \\
\hline & photo-Fenton & C. Segura et al. [8] & $50 \%$ & 1 min \\
\hline & $\begin{array}{l}\text { Electrocatalytic } \\
\text { oxidation }\end{array}$ & P. Garrett. [10] & $78 \%$ & $53.2 \mathrm{~min}$ \\
\hline & Electro-Fenton & O. Igles ias et al. [11] & $100 \%$ & $120 \mathrm{~min}$ \\
\hline & Electrocoagulation & $\begin{array}{l}\text { This study using } \\
\text { (Fe electrode) }\end{array}$ & $95 \%$ & $60 \mathrm{~min}$ \\
\hline & Electrocoagulation & $\begin{array}{l}\text { This study using } \\
\text { (Al electrode) }\end{array}$ & $80.8 \%$ & $90 \mathrm{~min}$ \\
\hline
\end{tabular}

Table 3: Comparison between the Electrocoagulation method for removal of imidacloprid with other methods. 
Citation: Nasser Ghalwa MA, Nader Farhat B (2015) Removal of Imidacloprid Pesticide by Electrocoagulation Process using Iron and aluminum Electrodes. J Environ Anal Chem 2: 154. doi:10.4172/2380-2391.1000154

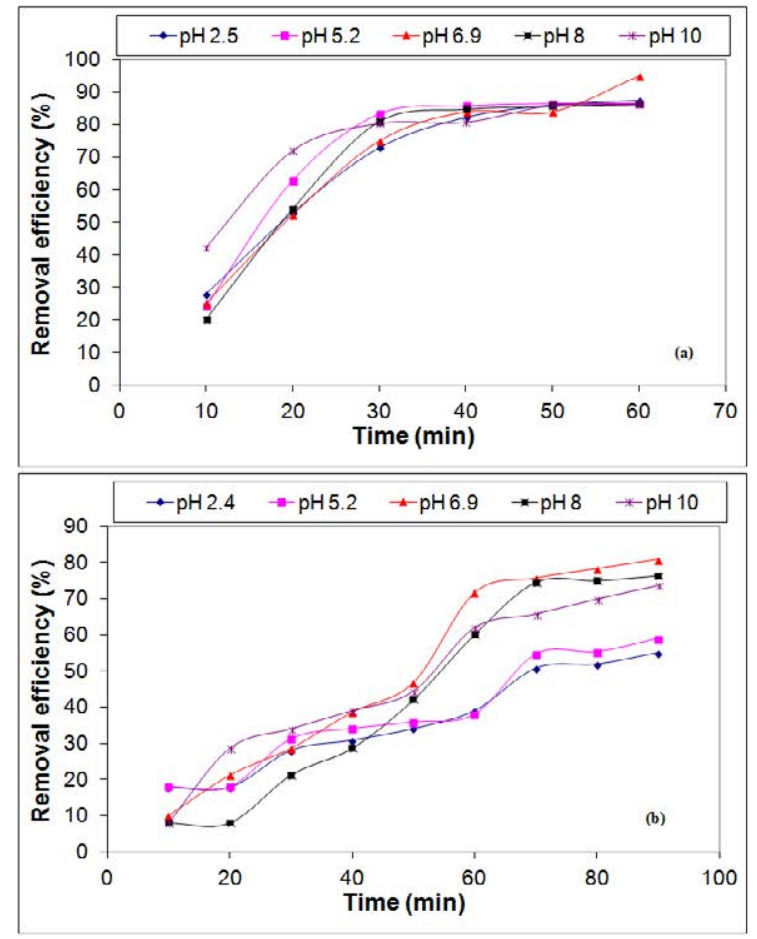

Figure 4: Effect of $\mathrm{pH}$ on the efficiency of imidacloprid removal using Fe (a) and $\mathrm{Al}$ (b) electrodes. Initial concentration of the pesticide $=50 \mathrm{mg} / \mathrm{L}$, volume of the solution $=100 \mathrm{ml}, \mathrm{NaCl}$ concentration $=1 \mathrm{~g} / \mathrm{L}$, current density of $18.5 \mathrm{~mA} / \mathrm{cm}^{2}$ inter electrode distance $=1 \mathrm{~cm}$, dimension of the electrodes $=17 \mathrm{~mm} \times 10 \mathrm{~mm}$ and temperature $=20^{\circ} \mathrm{C}$.

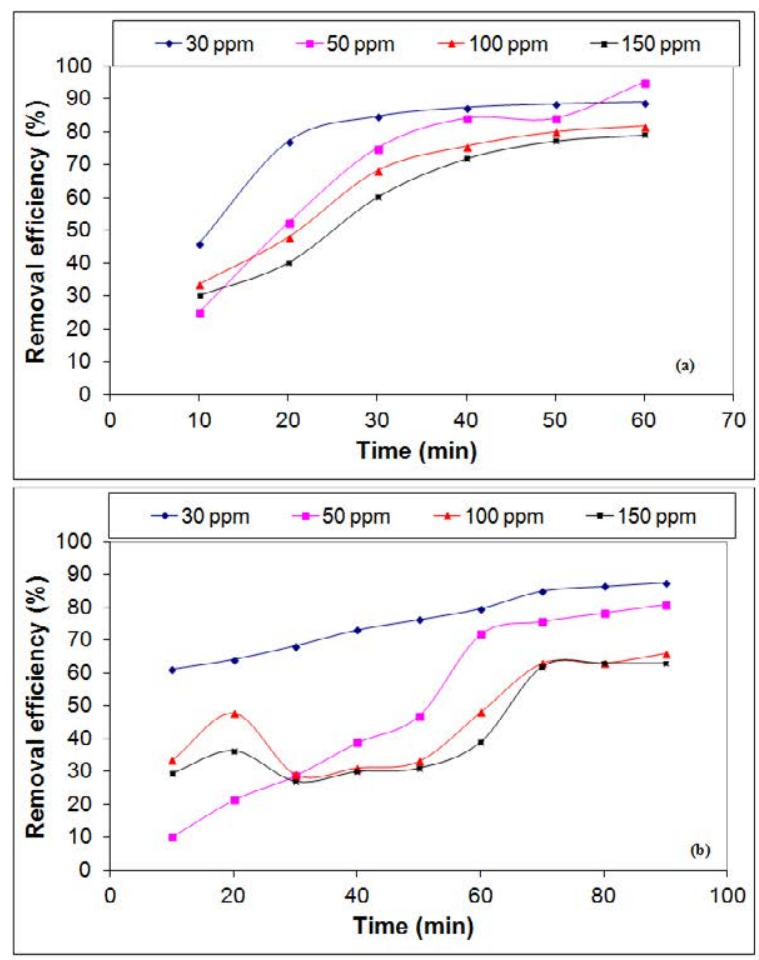

Figure 5: Effect of initial concentration on the efficiency of imidacloprid removal using $\mathrm{Fe}(\mathrm{a})$ and $\mathrm{Al}(\mathrm{b})$ electrodes. $\mathrm{NaCl}$ concentration $=1 \mathrm{~g} / \mathrm{L}$, volume of the solution $=100 \mathrm{ml}$, current density of $18.5 \mathrm{~mA} / \mathrm{cm}^{2}, \mathrm{pH}=6.9$, inter electrode distance $=1 \mathrm{~cm}$, dimension of the electrodes $=17 \mathrm{~mm} \times 10$ $\mathrm{mm}$ and temperature $=20^{\circ} \mathrm{C}$.

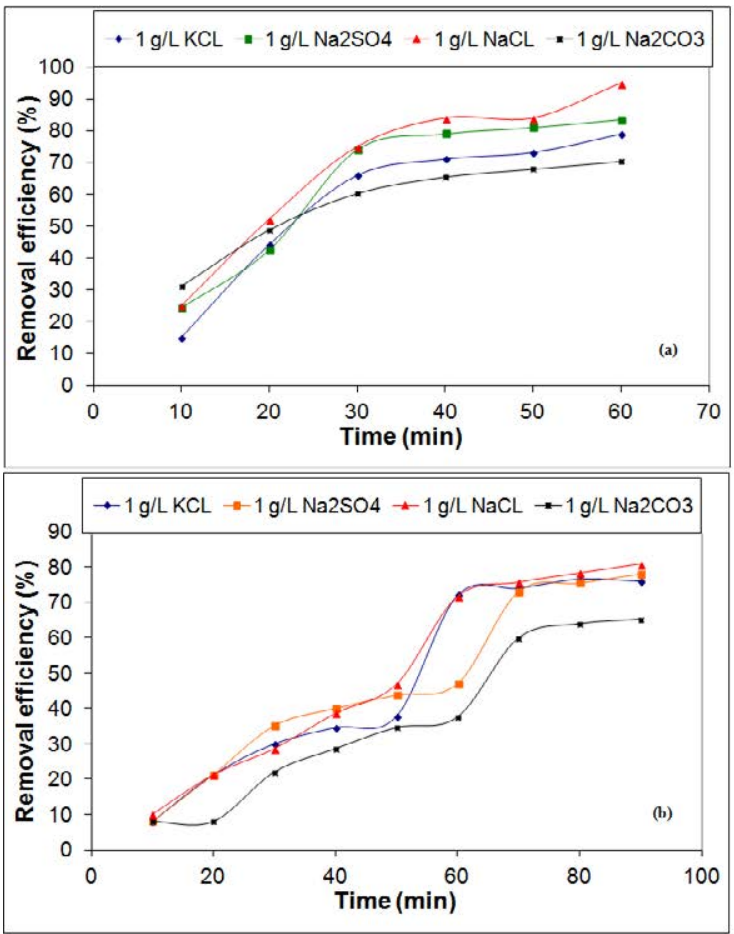

Figure 6: Effect of type of electrolyte on the efficiency of imidacloprid removal using $\mathrm{Fe} \mathrm{(a)}$ and $\mathrm{Al}(\mathrm{b})$ electrodes. Initial concentration of the pesticide $=50$ $\mathrm{mg} / \mathrm{L}$, volume of the solution $=100 \mathrm{ml}$, current density of $18.5 \mathrm{~mA} / \mathrm{cm}^{2}, \mathrm{pH}=6.9$, inter electrode distance $=1 \mathrm{~cm}$, dimension of the electrodes $=17 \mathrm{~mm} \times 10 \mathrm{~mm}$ and temperature $=20^{\circ} \mathrm{C}$.
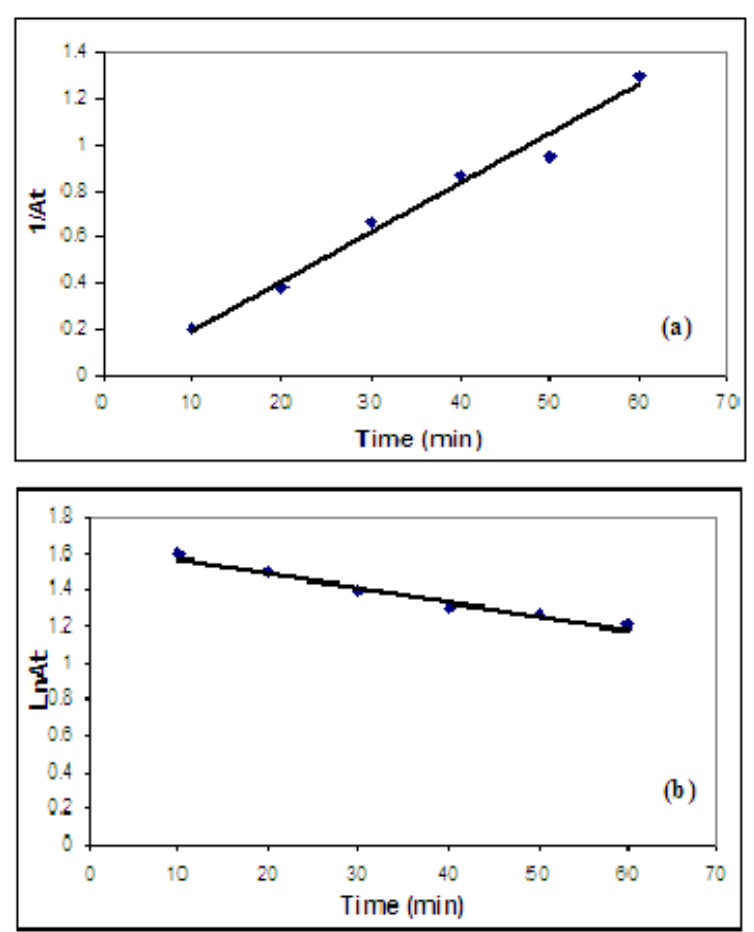

Figure 7: Relation between $1 / A_{t}$ and $L n A_{t}$ against the time for imidacloprid removal using $\mathrm{Fe}(\mathrm{a})$ and $\mathrm{Al}(\mathrm{b})$ electrodes. Initial concentration of the pesticide $=50 \mathrm{mg} / \mathrm{L}$, volume of the solution $=100 \mathrm{ml}$, current density of $18.5 \mathrm{~mA} / \mathrm{cm}^{2}$, $\mathrm{pH}=6.9, \mathrm{NaCl}$ concentration $=1 \mathrm{~g} / \mathrm{L}$, inter electrode distance $=1 \mathrm{~cm}$, dimension of the electrodes $17 \mathrm{~mm} \times 10 \mathrm{~mm}$ and temperature $=20^{\circ} \mathrm{C}$ 
Citation: Nasser Ghalwa MA, Nader Farhat B (2015) Removal of Imidacloprid Pesticide by Electrocoagulation Process using Iron and aluminum Electrodes. J Environ Anal Chem 2: 154. doi:10.4172/2380-2391.1000154

7(b) represent the removal of imidacloprid exhibited pseudo second order with good correlation coefficients $(>0.98)$ using Fe electrodes according to following equation:

$$
1 / A_{t}-1 / A_{0}=K t
$$

and exhibited pseudo first order with good correlation coefficients (>0.97) for $\mathrm{Al}$ electrodes according to following equation:

$$
\operatorname{Ln} A / A_{0}=-k t
$$

Where $A_{o}, A_{t}, t$, and $k$ are the pesticide absorbance at initial concentration, pesticide absorbance at each time, time of reaction ( $\min$ ), and reaction rate constant, respectively. Figures 7 (a) and $7(\mathrm{~b})$ explain the plot of pseudo second order and pseudo first order equations for the pesticide removal using $\mathrm{Fe}$ and $\mathrm{Al}$ electrodes respectively. The straight lines in plot show a good agreement of experimental data with the kinetic models for different removal rates. The calculated $\mathrm{k}$ values from the plot (straight line) of Figures 7(a) and 7(b) were $0.0212 \mathrm{~mol}^{-}$ ${ }^{1} \mathrm{dm}^{3} \mathrm{~min}^{-1}$ and $0.0079 \mathrm{~min}^{-1}$ using Fe and $\mathrm{Al}$ electrodes respectively.

\section{Conclusion}

The removal efficiency of imidacloprid from aqueous solution was examined by electrocoagulation using iron $(\mathrm{Fe})$ and aluminum $(\mathrm{Al})$ electrodes. The effects of initial $\mathrm{pH}$, initial abamectin concentration, current density, type electrolyte, salt concentration, and temperature were investigated on removal efficiency and COD. It was observed that these variables significantly affected the imidacloprid pesticide removal efficiency. The optimum imidacloprid pesticide removal was obtained with typical operating conditions: an initial $\mathrm{pH}$ of 6.9 , an initial pesticide concentration of $50 \mathrm{mg} / \mathrm{L}$, current density $18.5 \mathrm{~mA} /$ $\mathrm{cm}^{2}$, salt concentration of $1 \mathrm{~g} / \mathrm{L}$ and temperature of $20^{\circ} \mathrm{C}$, the results showed that imidacloprid and COD removal were 95\% and $89.5 \%$ by using $\mathrm{Fe}$ and were $80.8 \%$ and $73.1 \%$, by using $\mathrm{Al}$ electrodes. The removal of pesticide was exhibited pseudo second order with rate constant $0.0212 \mathrm{~mol}^{-1} \mathrm{dm}^{3} \mathrm{~min}^{-1}$ for Fe electrode and pseudo first order with rate constant $0.0079 \mathrm{~min}^{-1}$ using $\mathrm{Al}$ electrodes.

\section{References}

1. Tan GH, Vijayaletchumy K (1994) Organochlorine pesticide residue levels in peninsular Malaysian rivers. Bull Environ Contam Toxicol 53: 351-356.

2. Plakas KV, Karabelas, AJ (2009) Triazine retention by nanofiltration in the presence of organic matter: The role of humic substance characteristics. J Membr Sci 336: 86-100.

3. Tisler T, Jemec A, Mozetic B, Trebse P (2009) Hazard identification of imidacloprid to aquatic environment. Chemosphere 76: 907-914.

4. Ding T, Lavine BK, Journal of Chromatography A 1218 (2011) 9221-9226.

5. Fossen M (2006) Environmental Fate of Imidacloprid. Environmental monitoring $1-16$.

6. David D, George IA, Peter JV (2007) Toxicology of the newer neonicotinoid insecticides: imidacloprid poisoning in a human. Clin Toxicol (Phila) 45: 485486 .

7. Moza PN, Husteri K, Feicht E, Kettrup A (1998) Photolysis of Imidacloprid in aqueous solution chemosphere $36: 497-502$.

8. Segura C, Zaror C, Mansilla HD, Mondaca MA (2008) Imidacloprid oxidation by photo-Fenton reaction. J Hazard Mater 150: 679-686.

9. Bourgin M, Violleau F, Debrauwer L, Albet J (2011) Ozonation of imidacloprid in aqueous solutions: reaction monitoring and identification of degradation products. J Hazard Mater 190: 60-68.

10. Garrett P (2013) Electrochemical degradation of some pesticides in agricultural wastewater by using modified electrode. International Journal of Agr and Env 61.

11. Iglesias O, Gómez J, Pazos M, Sanromán MA (2014) Electro-Fenton oxidation of imidacloprid by $\mathrm{Fe}$ alginate gel beads Applied Catalysis B. Environmental 144: 416-424.
2. Arsand DR, Kümmerer K, Martins AF (2013) Removal of dexamethasone from aqueous solution and hospital wastewater by electrocoagulation. Sci Total Environ 443: 351-357.

13. Gengec E, Kobya M, Demirbas E, Akyol A, Oktor K (2012) Electrochemical treatment of Baker's yeast wastewater containing melanoidin: optimization through response surface methodology. Water Sci Technol 65: 2183-2190.

14. Wang CT, Chou WL, Kuo YM (2009) Removal of COD from laundry wastewater by electrocoagulation/electroflotation. J Hazard Mater 164: 81-86.

15. Ahmadi S, Sardari E, Javadian H, Katal R ,Vafaie SM (2013) Removal of oil from biodiesel wastewater by electrocoagulation method. Korean J Chem Eng 30: 634-641.

16. Ngamlerdpokin K, Kumjadpai S, Chatanon P, Tungmanee U, Chuenchuanchom $\mathrm{S}$, et al. (2011) Remediation of biodiesel wastewater by chemical- and electrocoagulation: a comparative study. J Environ Manage 92: 2454-2460.

17. Eryuruk K, Tezcan U, Ogutveren UB (2011) 2nd International Conference on Chemical Engineering and Applications, IPCBEE, 23, 134.

18. Ni'am MF, Othman F, Sohaili J, Fauzia Z (2007) Electrocoagulation technique in enhancing $C O D$ and suspended solids removal to improve wastewater quality. Water Sci Technol 56: 47-53.

19. Bazrafshan E, Aldin Ownagh K, Mahvi AH (2012) Environ J Chem 9: 2297.

20. Malakootian M, Yousefi N and Fatehizadeh A (2011) Int J Environ Sci Technol 8: 107.

21. Shafaei A, Rezayee M, Arami M and Nikazar M (2010) Desalination 260: 23.

22. Cheng N, Gao H, Deng J, Wang B, Xu R, et al. (2012) Removal of chloramphenicol by macroporous adsorption resins in honey: a novel approach on reutilization of antibiotics contaminated honey. J Food Sci 77: T169-172.

23. Fuentes MS, Benimeli CS, Cuozzo SA, Amoroso MJ (2010) Isolation of pesticide-degrading actinomycetes from a contaminated site: Bacterial growth, removal and dechlorination of organochlorine pesticides. International Biodeterioration and Biodegradation 64: 434e441.

24. Shawaqfeh AT (2010) Removal of pesticides from water using anaerobicaerobic biological treatment. Chinese J Chem Eng 18: 672-680.

25. Plakas KV, Karabelas AJ, Wintgens T, Melin T (2006) A study of selected herbicides retention by nanofiltration membranes-The role of organic fouling. J Membr Sci 284: 291-230.

26. Ikeura H, Kobayashi F, Tamaki M (2011) Removal of residual pesticide fenitrothion, in vegetables by using ozone microbubbles generated by different methods. J Food Eng 103: 345-349.

27. Shawaqfeh AT, Al Momani FA (2010) Photocatalytic treatment of water soluble pesticide by advanced oxidation technologies using UV light and solar energy. Solar Energy 84: 1157-1165

28. Behloul M, Grib H, Drouiche N, Abdi N, Lounici H, Mameri N ( 2013) Removal of Malathion Pesticide from Polluted Solutions by Electrocoagulation: Modeling of Experimental Results using Response Surface Methodology . Separation Science and Technology 48: 664-672.

29. Babu BR, Meera KMS, Venkatesan $P$ (2011) Removal of pesticides from wastewater by electrochemical methods $A$ comparative approach. Sustain Environ Res 21: 401-406 .

30. Abdel-Gawad SA, Baraka AM, Omran KA, Mokhtar MM (2012) Removal of Some Pesticides from the Simulated Waste Water by Electrocoagulation Method Using Iron Electrodes. Int J Electrochem Sci 7: 6654-6665.

31. Nasser M, Ghalwa A, Farhat NB (2015) Removal of Abamectin Pesticide by Electrocoagulation Process Using Stainless Steel and Iron Electrodes. J Environ Anal Chem 3: 1-7.

32. Mollah MY, Schennach R, Parga JR, Cocke DL (2001) Electrocoagulation (EC)--science and applications. J Hazard Mater 84: 29-41.

33. Carneiro PA, Fugivara CS, Nogueira FP, Boralle N, Zanoni VB (2003) A Comparative on Chemical and Electrochemical Degradation of Reactive Blue 4 Dye. Portugaliae Electrochimica Acta 21: 49-67.

34. Chithra K, Thilakavathi R, Arul Murugan A, Marimuthu C, Balasubramanian N (2008) Treatment of TextileEffluent Using Sacrificial Electrode. Modern applied science 4 . 
Citation: Nasser Ghalwa MA, Nader Farhat B (2015) Removal of Imidacloprid Pesticide by Electrocoagulation Process using Iron and aluminum Electrodes. J Environ Anal Chem 2: 154. doi:10.4172/2380-2391.1000154

35. Larue O, Vorobiev E (2003) Floc Size Estimation in Iron Induced Electrocoagulation and Coagulation using Sedimentation Data. Int $\mathrm{J}$ Miner Proc 71: 1-5

36. Benefield LD, Judkins JF, Weand BL (1982) Process chemistry for water and wastewater treatment. Prentice-Hall Inc., Publishers, Englewood Cliffs, 510.

37. Chou WL (2010) Removal and adsorption characteristics of polyvinyl alcohol from aqueous solutions using electrocoagulation. J Hazard Mater 177: 842850

38. Liu H, Zhao X, Qu J (2010) Electrocoagulation in Water Treatment. In: C. Comninellis and G. Chen, (eds). Electrochemistry for the Environment. New York:Springer Science + Business Media pp: 245-262.

39. Chen G, Chen PL, Yue, Seperation Purif Technol 19: 65-76.

40. Daneshvar N, Ashassi SH, Kasiri MB (2004) Decolorization of dye solution containing Acid Red 14 by electrocoagulation with a comparative investigation of different electrode connections. J Hazard Mater 112: 55-62.

41. Daneshvar N, Sorkhabi HA, Kasiri MB (2004) Decolorization of dye solution containing Acid Red 14 by electrocoagulation with a comparative investigation of different electrode connections. J Hazard Mater 112: 55-62.

42. Modirshahla N, Behnajady MA, Mohammadi-Aghdam S (2008) Investigation of the effect of different electrodes and their connections on the removal efficiency of 4-nitrophenol from aqueous solution by electrocoagulation. J Hazard Mater 154: 778-786.

43. Golder AK, Hridaya N, Samanta AN, Ray S (2005) Electrocoagulation of methylene blue and eosin yellowish using mild steel electrodes. J Hazard Mater 127: 134-140.

44. Lee WJ, Pyun SI (1999) Effects of hydroxide ion addition on anodic dissolution of pure aluminum in chloride ion-containing solution. Electrochim Acta 44 4041-4049.

45. Dash BP, Chaudhari S (2005) Electrochemical denitrificaton of simulated ground water. Water Res 39: 4065-4072. 